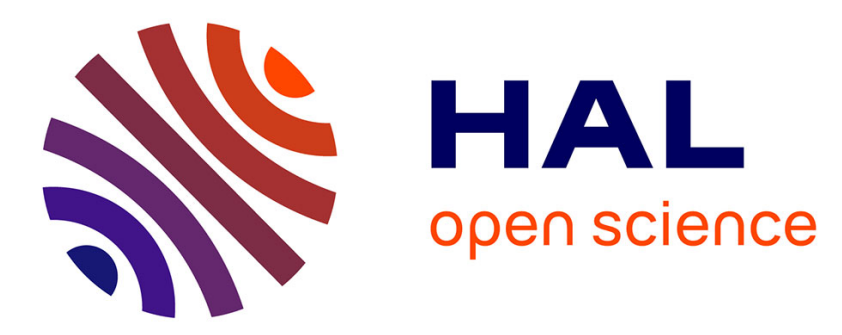

\title{
Differential gene expression in the brain of in response to exposure to polychlorinated biphenyls (PCBs)
}

Bowen Li, Chonggang Wang, Kai Ye, Ang Yu, Yixin Chen, Zhenghong Zuo

\section{To cite this version:}

Bowen Li, Chonggang Wang, Kai Ye, Ang Yu, Yixin Chen, et al.. Differential gene expression in the brain of in response to exposure to polychlorinated biphenyls (PCBs). Marine Environmental Research, 2008, 66 (5), pp.548. 10.1016/j.marenvres.2008.09.001 . hal-00563053

\section{HAL Id: hal-00563053 https://hal.science/hal-00563053}

Submitted on 4 Feb 2011

HAL is a multi-disciplinary open access archive for the deposit and dissemination of scientific research documents, whether they are published or not. The documents may come from teaching and research institutions in France or abroad, or from public or private research centers.
L'archive ouverte pluridisciplinaire $\mathbf{H A L}$, est destinée au dépôt et à la diffusion de documents scientifiques de niveau recherche, publiés ou non, émanant des établissements d'enseignement et de recherche français ou étrangers, des laboratoires publics ou privés. 


\section{Accepted Manuscript}

Differential gene expression in the brain of Sebastiscus marmoratus in response to exposure to polychlorinated biphenyls (PCBs)

Bowen Li, Chonggang Wang, Kai Ye, Ang Yu, Yixin Chen, Zhenghong Zuo

PII:

S0141-1136(08)00205-5

DOI:

10.1016/j.marenvres.2008.09.001

Reference:

MERE 3287

To appear in:

Marine Environmental Research

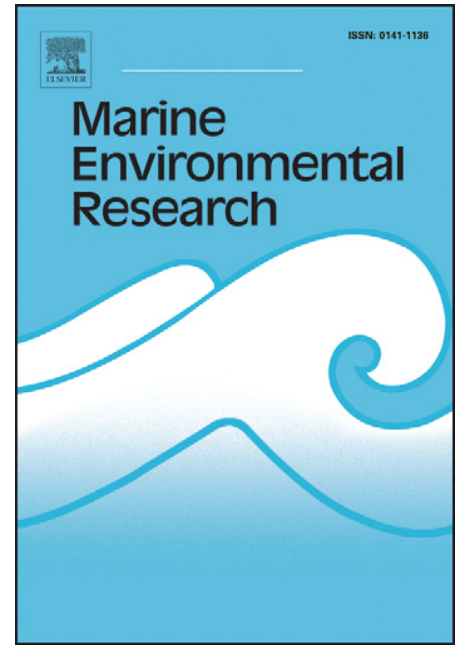

Received Date: $\quad 30$ April 2008

Revised Date: $\quad 30$ July 2008

Accepted Date: $\quad 5$ September 2008

Please cite this article as: Li, B., Wang, C., Ye, K., Yu, A., Chen, Y., Zuo, Z., Differential gene expression in the brain of Sebastiscus marmoratus in response to exposure to polychlorinated biphenyls (PCBs), Marine Environmental Research (2008), doi: 10.1016/j.marenvres.2008.09.001

This is a PDF file of an unedited manuscript that has been accepted for publication. As a service to our customers we are providing this early version of the manuscript. The manuscript will undergo copyediting, typesetting, and review of the resulting proof before it is published in its final form. Please note that during the production process errors may be discovered which could affect the content, and all legal disclaimers that apply to the journal pertain. 
1 Differential gene expression in the brain of Sebastiscus marmoratus in response to exposure to polychlorinated biphenyls (PCBs)

3 


\section{Abstract}

16 Effects of exposure to polychlorinated biphenyls (PCBs) on Sebastiscus marmoratus were

17 investigated using a suppression subtractive hybridization method. A total of 108 gene

sequences were identified as having the potential for being differentially expressed, and 45 could be identified with homologous database sequences. Functions with which they were associated included long-term potentiation and neurotransmitter release, neuroendocrine, mitosis and cell proliferation, energy-related metabolism, general metabolism, signal protein, hemopoiesis system, immune system, and structure. The expression of 17 of these genes was analyzed in the brain using real time fluorescent quantitative PCR. The present study provided a basis for studying the response of fish to PCB exposure and allowed the characterization of new potential neurotoxicol biomarkers of PCB contamination in seawater.

Keywords: polychlorinated biphenyls, neurotoxicity, Sebastiscus marmoratus, suppression subtractive hybridization library, real time PCR 


\section{Introduction}

Polychlorinated biphenyls (PCBs) are a class of industrial compounds consisting of paired phenyl rings with various degrees of chlorination (Tilson and Kodavanti, 1997). Although their production was banned in the 1970s, this was after more than a billion kilograms were produced, and so they remain ubiquitous, persistent environmental contaminants that are routinely found in samples of human and animal tissues (Fisher, 1999). The central nervous system is one of the target organs for PCBs (Altmann et al., 2001), and PCBs are known to be neurotoxic, inducing neurochemical and behavioral disruptions in humans and experimental animals (Brouwer et al., 1995). Cognitive/motor deficits were found among children who had accidental perinatal exposure to PCBs in cooking oil (Rogan and Gladen, 1992).

It has been proved that disruption of the hypothalamus-pituitary-interrenal axis by PCBs involves brain glucocorticoid receptor down-regulation (Aluru et al., 2004). The effects of PCBs on brain development may be attributable, at least in part, to their ability to reduce circulating levels of thyroid hormone. However, the developmental effects of PCB exposure are not simply a function of PCB-induced hypothyroidism (Zoeller et al., 2000). A high dose of PCBs appears to result in neuronal loss, as reflected by a decrease in glucocorticoid receptor (GR), heat shock protein 90 (hsp90), and heat shock protein 70 (hsp70) expression, leading to the disruption of the negative feedback regulation of cortisol during stress (Aluru et al., 2004). In recent years, learning deficits and endocrine disrupting actions have been observed whereby the non-coplanar congener exhibits neurotoxicities via different mechanisms with coplanar PCB (Zhou et al., 2004). 
However, the neurotoxic mechanism of PCBs is complex and actually still unclear. The aim of this study was to identify the transcripts which were up- or down-regulated by PCBs in the brain of the marine fish Sebastiscus marmoratus using suppression PCR subtractive hybridization ( $\mathrm{SSH}$ ). This is a highly effective genome-wide approach that enriches for differentially expressed mRNA transcripts by generating subtracted cDNA libraries (Alonso and Leong, 2002; Diatchenko et al., 1996; Straub et al., 2004). Differential expression of some of the genes identified by SSH was confirmed by real time quantitative PCR. This method is very sensitive for the detection and quantification of gene expression levels, in particular for low abundance mRNA (Feng et al., 2007).

\section{Materials and methods}

\subsection{Chemicals}

Aroclor 1254, a commercial PCB mixture was purchased from Sigma-Aldrich (Sigma-Aldrich Co., USA), and a PCR-Select cDNA Subtraction Kit was obtained from BD Biosciences (BD Biosciences, UK). All other chemicals were of analytical grade and were obtained from commercial sources.

\subsection{Treatments and sample collection}

All animal experiments were conducted according to the research protocols approved by Xiamen University Institutional Animal Care and Use Committee. Female Sebastiscus marmoratus weighing 23-27 g, were captured from the coastal area of Xiamen city, Fujian Province, China. Before the exposure experiment, the fish were acclimated in tanks (25 fish in each tank) containing $50 \mathrm{~L}$ of aerated sand-filtered seawater, with natural photoperiod 
for 7 days. Fish were dosed via single intraperitoneal injection with PCBs ( $3 \mathrm{mg} / \mathrm{kg}$ body weight in corn oil) or with only corn oil as a control. After 3 days, fish were randomly sampled from each group. The isolated brains were frozen in liquid $\mathrm{N}_{2}$ and immediately stored at $-80{ }^{\circ} \mathrm{C}$ until analysis.

\subsection{Suppression subtractive hybridization}

For the SSH procedure (PCR-Select cDNA Subtraction Kit, BD Biosciences, UK) mRNA was isolated from fish brains (RNAiso Reagent and Oligotex $^{\text {TM }}$-dT30 $<$ Super $>$ mRNA Purification Kit, TaKaRa Biotechnology (Dalian), PR. China) and two libraries constructed in a pMD18-T vector (TaKaRa Biotechnology (Dalian), PR. China), enriched for genes which had been up-regulated (forward subtracted) or down-regulated (reverse subtracted) in response to PCBs. For each subtracted cDNA library, 150 random white colonies were selected and PCR amplifications were performed with nested PCR (primer sequences: forward 5'-TCG AGC GGC CGC CCG GGC AGG T-3', reverse 5'-AGC GTG GTC GCG GCC GAG GT-3'). Candidate positive clones from the subtracted cDNA library were selected for sequencing. The sequence data were analyzed using the Vec Screen program (NCBI) for vector masking, and all adaptor sequences were removed. Each sequence of the isolated clones was used for homology searches in GenBank by BLASTN $(\mathrm{NCBI})$

\subsection{Real time fluorescent quantitative PCR}

The real time fluorescent quantitative PCR analysis used total RNA isolated from single-brain pools $(n=6)$. SYBR green I was used as the fluorescent dye for real time quantitative PCR on a Rotorgene 3000 (ABI, USA). The housekeeping gene of beta-actin 
was used as the endogenous assay control (primer sequences: forward 5'-AGG GAA ATC GTG CGT G-3', reverse 5'-ATG ATG CTG TTG TAG GTG GT-3'). PCR reactions were performed in triplicate for each cDNA sample.

The Relative Expression Software Tool - Multiple Condition Solver (REST-MCS @version 2) was used to calculate the relative expression of target genes mRNA in real time fluorescent quantitative PCR using Pair Wise Fixed Reallocation Randomization Test $\odot$ (Pfaffl et al., 2002). The mathematical model used is based on the mean crossing point deviation between sample and control group of target gene, normalized by the mean crossing point deviation of reference genes. Specific amplification efficiencies are included in the correction of the quantification ratio. Significant differences between groups were determined by ANOVA and secondary testing was done by using Tukey's LSD.

\section{Results and discussion}

PCR screening of colonies for recombinants was done with insert-specific primers in parallel with the generation of archived, 96-well format, bacterial stock cultures. Colonies containing inserts were identified using agarose gel electrophoresis of the PCR products. Eighty clones of forward subtraction and 28 of reverse subtraction were selected and sequenced. A total of 108 expressed gene sequences were identified by BLAST searches. Seventy-nine transcripts were obtained and analyzed by BLASTN (nucleic acid) and TBLASTX (translated protein query search) and a selection are shown in Table 1. The homology search revealed that 45 clones contained substantial sequence homologies $\left(E\right.$-value $<1 \mathrm{e}^{-6}$ ) with known gene fragments or full-length cDNAs (most belong to 
Tetraodon nigroviridis) and 34 possibly novel genes, showing no significant homologies with any known sequences in the GenBank.

The clones could be arranged into a number of distinct functional groups representative of protective mechanisms associated with responses to PCB exposure, including genes involved in PCB metabolism, such as cytochrome $b$ and cytochrome $c$ (Goksoyr and Forlin, 1992); some correlated with neural functions, such as snap25a (Roberts et al., 1998), rtnl (De Craene et al., 2006); and of mechanisms of energy metabolism and cellular regulation, while a number were cryptic (classifications are given in Table 1).

\section{Positions of Table 1}

The real time quantitative PCR primers for 20 candidate ESTs were designed, and 17 were used for quantitative PCR (Table 2). The differential expression of 17 ESTs included 10 which encoded known proteins likely to be involved in PCB neurotoxicity, 5 which belong to function-unknown cDNA/mRNA, and 2 were potentially novel gene transcripts. The results showed the presence of differentially expressed genes in the brains of the PCB-treated fish compared with the control group (Figure 1).

\section{Position of Table 2}

\section{Position of Figure 1}

Long-term potentiation (LTP) is a persistent synaptic enhancement induced by high-frequency stimulation of afferents and has been suggested to be an important component of the cellular basis of certain forms of memory and learning (Collingridge, 1987). LTP has been introduced in neurotoxicological studies on PCBs, and PCB-induced 
LTP deficits reveal that there are multiple factors have to be considered besides the N-methyl-D-aspartate (NMDA) receptor (Altmann et al., 2001; Gilbert et al., 2000). In the present study, EST 13 and EST 14 contained substantial sequence homologies with genes of the $\alpha$-amino-3-hydroxy-5-methyl-4-isoxazolepropionic acid (AMPA) receptor $\beta$ subunit and calmodulin respectively, which correspond to LTP (Sandkuhler, 2007). It has been reported that LTP deficits responding to PCBs can only be partly related to the reduction of binding sites for the NMDA receptor (Altmann et al., 2001). Our result suggested that the AMPA receptor was also induced by PCB-treatment. The down-regulation of these genes could induce LTP deficits, which may be one likely mechanism for neurochemical and behavioral disruptions responding to PCBs. EST 9 is homologous with the gene of $25 \mathrm{kDa}$ synaptosomal-associated protein (SNAP-25), which is a presynaptic protein involved in neurotransmitter exocytosis at the nerve terminal (Roberts et al., 1998). At the neuronal synapse, the central role of SNAP-25 is evident from the impairment of neuronal secretion by botulinum neurotoxin $\mathrm{A} / \mathrm{E}$, a toxin that proteolytically inactivates SNAP-25 (Hayashi et al., 1994). Moreover, loss of SNAP-25 expression in mice results in embryonic lethality late in gestation with evoked neurotransmitter release absent at the neuromuscular junction and central synapses (Washbourne et al., 2002). This study showed that the expression of SNAP-25 was decreased after PCB-treatment, which is likely to have induced the disruption of synaptic plasticity and LTP, resulting in the inordinateness of central neural system functions. EST 1 is homologous to a gene of Tob (the transducer of ErbB-2), which is well known as a negative regulator in peripheral cells (Matsuda et al., 
162

163

164

165

166

167

168

169

171

172

173

174

175

176

177

178

179

180

181

182

183

184

185

186

187

188

1996). The elevated expression level of Tob responding to PCB-treatment suggested that

Tob might be another potential core gene involved in the neurotoxicity of PCBs.

\section{Conclusions}

In conclusion, our results identified a number of ESTs suitable for further development as environmental biomarkers, most of which had novel sequences and although some remained cryptic, those putatively identified were informative regarding the potential mechanisms of $\mathrm{PCB}$ nuerotoxicity. However, further investigation is required to understand the effects of PCB-induced neurotoxicity in marine fish.

\section{Acknowledgements}

This work was supported by the National Natural Science Foundation (40606027) of China and by Fund (MEL0606) of the State Key Laboratory of Marine Environmental Science, Xiamen University, China. Professor John Hodgkiss is thanked for his assistance with English.

\section{References}

Alonso, M. and Leong, J.A., 2002. Suppressive subtraction libraries to identify interferon-inducible genes in fish. Mar Biotechnol (NY) 4, 74-80.

Altmann, L., Mundy, W.R., Ward, T.R., Fastabend, A. and Lilienthal, H., 2001. Developmental exposure of rats to a reconstituted PCB mixture or aroclor 1254: effects on long-term potentiation and [3H]MK-801 binding in occipital cortex and hippocampus. Toxicol Sci 61, 321-330.

Aluru, N., Jorgensen, E.H., Maule, A.G. and Vijayan, M.M., 2004. PCB disruption of the hypothalamus-pituitary-interrenal axis involves brain glucocorticoid receptor downregulation in anadromous Arctic charr. Am J Physiol Regul Integr Comp Physiol 287, R787-793.

Brouwer, A., Ahlborg, U.G., Van den Berg, M., Birnbaum, L.S., Boersma, E.R., Bosveld, B., Denison, M.S., Gray, L.E., Hagmar, L., Holene, E. and et al., 1995. Functional aspects of developmental toxicity of 
polyhalogenated aromatic hydrocarbons in experimental animals and human infants. Eur J Pharmacol 293, 1-40.

Collingridge, G., 1987. Synaptic plasticity. The role of NMDA receptors in learning and memory. Nature 330, 604-605.

De Craene, J.O., Coleman, J., Estrada de Martin, P., Pypaert, M., Anderson, S., Yates, J.R., 3rd, Ferro-Novick, S. and Novick, P., 2006. Rtn1p is involved in structuring the cortical endoplasmic reticulum. Mol Biol Cell 17, 3009-3020.

Diatchenko, L., Lau, Y.F., Campbell, A.P., Chenchik, A., Moqadam, F., Huang, B., Lukyanov, S., Lukyanov, K., Gurskaya, N., Sverdlov, E.D. and Siebert, P.D., 1996. Suppression subtractive hybridization: a method for generating differentially regulated or tissue-specific cDNA probes and libraries. Proc Natl Acad Sci U S A 93, 6025-6030.

Feng, L., Miao, W. and Wu, Y., 2007. Differentially expressed genes of Tetrahymena thermophila in response to tributyltin (TBT) identified by suppression subtractive hybridization and real time quantitative PCR. Aquat Toxicol 81, 99-105.

Fisher, B.E., 1999. Most unwanted. Environ Health Perspect 107, A18-23.

Gilbert, M.E., Mundy, W.R. and Crofton, K.M., 2000. Spatial learning and long-term potentiation in the dentate gyrus of the hippocampus in animals developmentally exposed to Aroclor 1254. Toxicol Sci 57, 102-111.

Goksoyr, A. and Forlin, L., 1992. The Cytochrome P-450 System in Fish, Aquatic Toxicology and Environmental Monitoring Aquatic Toxicology 22, 25.

Hayashi, T., McMahon, H., Yamasaki, S., Binz, T., Hata, Y., Sudhof, T.C. and Niemann, H., 1994. Synaptic vesicle membrane fusion complex: action of clostridial neurotoxins on assembly. EMBO J 13, 5051-5061.

Matsuda, S., Kawamura-Tsuzuku, J., Ohsugi, M., Yoshida, M., Emi, M., Nakamura, Y., Onda, M., Yoshida, Y., Nishiyama, A. and Yamamoto, T., 1996. Tob, a novel protein that interacts with p185erbB2, is associated with anti-proliferative activity. Oncogene 12, 705-713.

Pfaffl, M.W., Horgan, G.W., Dempfle, L. Relative Expression Software Tool (REST@) for group-wise comparison and statistical analysis of relative expression results in real-time PCR. Nucleic Acids Res. 30, e36, 2002 .

Roberts, L.A., Morris, B.J. and O'Shaughnessy, C.T., 1998. Involvement of two isoforms of SNAP-25 in the expression of long-term potentiation in the rat hippocampus. Neuroreport 9, 33-36.

Rogan, W.J. and Gladen, B.C., 1992. Neurotoxicology of PCBs and related compounds. Neurotoxicology 13, 27-35.

Sandkuhler, J., 2007. Understanding LTP in pain pathways. Mol Pain 3, 9.

Straub, P.F., Higham, M.L., Tanguy, A., Landau, B.J., Phoel, W.C., Hales, L.S., Jr. and Thwing, T.K., 2004. Suppression subtractive hybridization cDNA libraries to identify differentially expressed genes from contrasting fish habitats. Mar Biotechnol (NY) 6, 386-399.

Tilson, H.A. and Kodavanti, P.R.S., 1997. Neurochemical effects of polychlorinated biphenyls: An overview and identification of research needs. Neurotoxicology 18, 727-743.

Washbourne, P., Thompson, P.M., Carta, M., Costa, E.T., Mathews, J.R., Lopez-Bendito, G., Molnar, Z., Becher, M.W., Valenzuela, C.F., Partridge, L.D. and Wilson, M.C., 2002. Genetic ablation of the t-SNARE SNAP-25 distinguishes mechanisms of neuroexocytosis. Nat Neurosci 5, 19-26.

Zhou, J., Qin, Z., Cong, L. and Xu, X., 2004. Research progress of the endocrine disrupting activities of polychlorinated biphenyls. Chinese Science Bulletin 49, 6 .

Zoeller, R.T., Dowling, A.L. and Vas, A.A., 2000. Developmental exposure to polychlorinated biphenyls 
233

234

exerts thyroid hormone-like effects on the expression of RC3/neurogranin and myelin basic protein messenger ribonucleic acids in the developing rat brain. Endocrinology 141, 181-189. 
235 Table 1 Characterisation of ESTs isolated from polychlorinated biphenyls-treated

236 Sebastiscus marmoratus.

237

238 Table 2 Primers used for real time quantitative PCR.

239

240 Figure 1. Figure 1. Gene expression profile of genes that were affected by PCBs: The

241 values were gene absolute regulation calculated by REST-MCS (C)- version 2 from

242 duplicate PCR determinations of three independent experiments for each set of conditions

243 tested (PCB-treated and the control). * \& ** indicate expression levels significantly

244 different from the control ( $p<0.05 \& p<0.01$ respectively) by Tukey’s LSD.

245 
Table 1

Characterisation of ESTs isolated from polychlorinated biphenyls-treated Sebastiscus marmoratus

\begin{tabular}{|c|c|c|c|c|c|}
\hline Homologous gene \& species & EST \# & $\begin{array}{l}\text { Insert } \\
\text { (bp) }\end{array}$ & $\begin{array}{l}E \text { - } \\
\text { value }\end{array}$ & Change & $\begin{array}{l}\text { GenBank } \\
\text { Access No. }\end{array}$ \\
\hline \multicolumn{6}{|l|}{$\underline{L T P}$ and neurotransmitter release related } \\
\hline Danio rerio $\mathrm{SNAP} 25 \mathrm{a}$ & 9 & 271 & $7 \mathrm{e}^{-47}$ & $\downarrow$ & $\underline{\text { FF403915 }}$ \\
\hline Carassius auratus kainate receptor (AMPA)beta subunit & 13 & 384 & $4 e^{-63}$ & $\downarrow$ & $\underline{F F 403841}$ \\
\hline O. latipes calmodulin & 14 & 541 & $2 \mathrm{e}^{-162}$ & $\downarrow$ & $\underline{\text { FF403842 }}$ \\
\hline Scophthalmus maximus clone sba441 ependymin & 20 & 486 & $2 \mathrm{e}^{-31}$ & $\downarrow$ & $\underline{\text { FF403849 }}$ \\
\hline \multicolumn{6}{|l|}{ Neuroendocrine } \\
\hline Gasterosteus aculeatus RTN1 & 8 & 321 & $7 \mathrm{e}^{-112}$ & $\downarrow$ & $\underline{\text { FF403914 }}$ \\
\hline Paralichthys olivaceus carboxypeptidase $\mathrm{H}$ & 22 & 587 & $2 \mathrm{e}^{-132}$ & & $\underline{\text { FF403851 }}$ \\
\hline \multicolumn{6}{|l|}{ Mitosis and Cell proliferation related } \\
\hline Gillichthys mirabilis transducer of ERBB-2(Tob) & 1 & 305 & $4 e^{-30}$ & $\uparrow$ & $\underline{\text { FF403837 }}$ \\
\hline Danio rerio dynein cytoplasmic 1 heavy chain 1 & 6 & 470 & $5 e^{-25}$ & $\downarrow$ & $\underline{F F 403892}$ \\
\hline Oreochromis mossambicus stathmin-like mRNA & 23 & 745 & 0.0 & $\downarrow$ & $\underline{\text { FF403852 }}$ \\
\hline
\end{tabular}

\section{$\underline{\text { Energy-related metabolism }}$}

Scombridae gen. sp. cytochrome c oxidase subunit VI b precursor

Sebastes maliger cytochrome $\mathrm{b}$

Rhabdosargus sarba sodium potassium ATPase $\alpha$ subunit

Helicolenus hilgendorfi ATPase 6

Kyphosus vaigiensis NADH dehydrogenase subunit 2
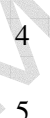

5

15

26

31

\section{General metabolism}

Danio rerio proteasome subunit Y

Sphyraena argentea lactate dehydrogenase-A

Danio rerio glutamic-oxaloacetic transaminase 1 , soluble

\section{Signal proteins}

Danio rerio zinc finger protein zic1

Sparus aurata V-Fos transformation effector-like protein

Danio rerio suppression of tumorigenicity 13 (colon carcinoma) (Hsp70 interacting protein)

Siniperca chuatsi clone C311 eukaryotic translation elongation factor -1 gamma

Danio rerio zinc finger protein zic1

Homo sapiens zinc finger protein 238 (ZNF238), transcript variant 1

$\begin{array}{llll}268 & 5 \mathrm{e}^{-60} & \uparrow & \underline{\mathbf{F F 4 0 3 8 7 0}} \\ 326 & 1 \mathrm{e}^{-91} & \uparrow & \underline{\mathbf{F F 4 0 3 8 8 1}} \\ 754 & 0.0 & \downarrow & \underline{\mathbf{F F 4 0 3 8 4 3}} \\ 165 & 2 \mathrm{e}^{-52} & \uparrow & \underline{\mathbf{F F 4 0 3 8 5 5}} \\ 272 & 7 \mathrm{e}^{-39} & \uparrow & \underline{\mathbf{F F 4 0 3 8 6 1}}\end{array}$

$\begin{array}{lllll}32 & 246 & 5 \mathrm{e}^{-32} & \downarrow & \underline{\mathbf{F F 4 0 3 8 6 2}} \\ 52 & 487 & 3 \mathrm{e}^{-47} & \uparrow & \underline{\mathbf{F F 4 0 3 8 8 4}} \\ 56 & 439 & 8 \mathrm{e}^{-92} & \downarrow & \underline{\mathbf{F F 4 0 3 8 8 8}}\end{array}$

$\begin{array}{lllll}10 & 379 & 4 \mathrm{e}^{-107} & \downarrow & \underline{\mathbf{F F 4 0 3 8 3 8}} \\ 11 & 468 & 0.0 & \downarrow & \underline{\mathbf{F F 4 0 3 8 3 9}} \\ 21 & 687 & 5 \mathrm{e}^{-122} & \downarrow & \underline{\mathbf{F F 4 0 3 8 5 0}} \\ 34 & 270 & 5 \mathrm{e}^{-63} & \uparrow & \underline{\mathbf{F F 4 0 3 8 6 4}} \\ 36 & 197 & 1 \mathrm{e}^{-41} & \downarrow & \underline{\mathbf{F F 4 0 3 8 6 6}} \\ 74 & 310 & 1 \mathrm{e}^{-18} & \downarrow & \underline{\mathbf{F F 4 0 3 9 0 8}} \\ & & & & \end{array}$




\begin{tabular}{|c|c|c|c|c|c|}
\hline Homologous gene \& species & EST \# & $\begin{array}{l}\text { Insert } \\
\text { (bp) }\end{array}$ & $\begin{array}{l}E \text { - } \\
\text { value }\end{array}$ & Change & $\begin{array}{l}\text { GenBank } \\
\text { Access No. }\end{array}$ \\
\hline \multicolumn{6}{|l|}{ Immune system } \\
\hline Epinephelus akaara clone 004 MHC class I alpha antigen & 25 & 353 & $5 \mathrm{e}^{-11}$ & $\uparrow$ & $\underline{\text { FF403854 }}$ \\
\hline \multicolumn{6}{|l|}{ Hemopoiesis system } \\
\hline Oryzias latipes embryonic alpha-type globin & 12 & 371 & $3 e^{-59}$ & $\downarrow$ & $\underline{\text { FF403840 }}$ \\
\hline \multicolumn{6}{|l|}{$\underline{\text { Ribosomal proteins }}$} \\
\hline Platichthys flesus $60 \mathrm{~S}$ ribosomal protein L28 & 24 & 308 & $1 \mathrm{e}^{-125}$ & $\uparrow$ & $\underline{\text { FF403853 }}$ \\
\hline Paralichthys olivaceus ribosomal protein L17 & 28 & 456 & $1 \mathrm{e}^{-145}$ & $\uparrow$ & $\underline{F F 403857}$ \\
\hline Siniperca chuatsi clone C426 60S ribosomal protein L35 & 29 & 180 & $6 \mathrm{e}^{-71}$ & $\uparrow$ & $\underline{F F 403858}$ \\
\hline Pagrus major 60S ribosomal protein L24 & 30 & 346 & $6 \mathrm{e}^{-88}$ & & $\underline{\text { FF403860 }}$ \\
\hline Solea senegalensis ribosomal protein $\mathrm{L} 35 \mathrm{a}$ & 51 & 394 & $3 \mathrm{e}^{-122}$ & $\uparrow$ & $\underline{\text { FF403883 }}$ \\
\hline Siniperca chuatsi clone $\mathrm{C} 123$ ribosomal protein $\mathrm{L} 7$ & 57 & 561 & 0.0 & $\downarrow$ & $\underline{\text { FF403889 }}$ \\
\hline Pagrus major ribosomal protein L37 & 65 & 259 & $2 e^{-76}$ & $\uparrow$ & $\underline{\text { FF403898 }}$ \\
\hline
\end{tabular}

\section{Identified genes but function unknown}

Tetraodon nigroviridis full-length cDNA

Tetraodon nigroviridis full-length cDNA

Gasterosteus aculeatus clone CNB134-E09 mRNA

Tetraodon nigroviridis full-length cDNA

Tetraodon nigroviridis full-length cDNA

Tetraodon nigroviridis full-length cDNA

Gasterosteus aculeatus clone CFW195-D 03 mRNA

Tetraodon nigroviridis full-length cDNA

Tetraodon nigroviridis full-length cDNA

Gasterosteus aculeatus clone CGX01-B09 mRNA

Gasterosteus aculeatus clone CNB24-E09 mRNA

Tetraodon nigroviridis full-length cDNA

Gasterosteus aculeatus clone CNB134-E09 mRNA

\section{Unidentified genes}

No homologous region

No homologous region

No homologous region

No homologous region

No homologous region

No homologous region

No homologous region

No homologous region

No homologous region

\begin{tabular}{|c|c|c|c|c|}
\hline 7 & 428 & $1 \mathrm{e}^{-61}$ & $\downarrow$ & $\underline{F F 403903}$ \\
\hline 16 & 342 & $3 e^{-25}$ & $\downarrow$ & FF403844 \\
\hline 17 & 467 & $1 e^{-52}$ & $\downarrow$ & $\underline{\text { FF403845 }}$ \\
\hline 18 & 262 & $6 e^{-21}$ & $\downarrow$ & $\underline{F F 403846}$ \\
\hline 19 & 300 & $2 \mathrm{e}^{-16}$ & $\downarrow$ & FF403847 \\
\hline 27 & 410 & $4 \mathrm{e}^{-127}$ & $\uparrow$ & $\underline{\text { FF403856 }}$ \\
\hline 33 & 220 & $1 \mathrm{e}^{-7}$ & $\uparrow$ & $\underline{\text { FF403863 }}$ \\
\hline 38 & 474 & $2 \mathrm{e}^{-10}$ & $\uparrow$ & $\underline{\text { FF403868 }}$ \\
\hline 49 & 111 & $3 e^{-10}$ & $\uparrow$ & FF403880 \\
\hline 54 & 514 & $3 e^{-60}$ & $\downarrow$ & FF403886 \\
\hline 62 & 335 & $7 \mathrm{e}^{-09}$ & $\uparrow$ & $\underline{\text { FF403895 }}$ \\
\hline 73 & 453 & $3 e^{-15}$ & $\uparrow$ & $\underline{F F 403907}$ \\
\hline 78 & 264 & $5 e^{-29}$ & $\downarrow$ & $\underline{\text { FF403912 }}$ \\
\hline 2 & 423 & - & $\uparrow$ & $\underline{\text { FF403848 }}$ \\
\hline 3 & 453 & - & $\uparrow$ & $\underline{\text { FF403859 }}$ \\
\hline 35 & 392 & - & $\uparrow$ & FF403865 \\
\hline 37 & 191 & - & $\uparrow$ & $\underline{\text { FF403867 }}$ \\
\hline 39 & 328 & - & $\uparrow$ & $\underline{\text { FF403869 }}$ \\
\hline 40 & 548 & - & $\uparrow$ & FF403871 \\
\hline 41 & 424 & - & $\downarrow$ & $\underline{F F 403872}$ \\
\hline 42 & 496 & - & $\downarrow$ & FF403873 \\
\hline 43 & 627 & - & $\downarrow$ & FF403874 \\
\hline
\end{tabular}


Table 1 (continued)

\begin{tabular}{|c|c|c|c|c|c|}
\hline Homologous gene \& species & EST \# & $\begin{array}{l}\text { Insert } \\
\text { (bp) }\end{array}$ & $\begin{array}{l}E- \\
\text { value }\end{array}$ & Change & $\begin{array}{l}\text { GenBank } \\
\text { Access No. }\end{array}$ \\
\hline No homologous region & 44 & 267 & - & $\downarrow$ & $\underline{\text { FF403875 }}$ \\
\hline No homologous region & 45 & 595 & - & $\downarrow$ & $\underline{\text { FF403876 }}$ \\
\hline No homologous region & 46 & 756 & - & $\downarrow$ & $\underline{\text { FF403877 }}$ \\
\hline No homologous region & 47 & 767 & - & $\downarrow$ & $\underline{F F 403878}$ \\
\hline No homologous region & 48 & 611 & - & $\downarrow$ & FF403879 \\
\hline No homologous region & 50 & 179 & - & $\uparrow$ & FF403882 \\
\hline No homologous region & 53 & 1143 & - & $\uparrow$ & $\underline{F F 403885}$ \\
\hline No homologous region & 55 & 654 & - & $\downarrow$ & FF403887 \\
\hline No homologous region & 58 & 234 & - & $\downarrow$ & FF403890 \\
\hline No homologous region & 59 & 139 & - & $\downarrow$ & FF403891 \\
\hline No homologous region & 60 & 315 & - & $\downarrow$ & $\underline{\text { FF403893 }}$ \\
\hline No homologous region & 61 & 510 & - & $\downarrow$ & $\underline{\text { FF403894 }}$ \\
\hline No homologous region & 63 & 409 & - & $\uparrow$ & $\underline{\text { FF403896 }}$ \\
\hline No homologous region & 64 & 246 & - & $\uparrow$ & $\underline{F F 403897}$ \\
\hline No homologous region & 66 & 332 & - & $\uparrow$ & $\underline{\text { FF403899 }}$ \\
\hline No homologous region & 67 & 931 & - & $\downarrow$ & $\underline{\text { FF403900 }}$ \\
\hline No homologous region & 68 & 612 & - & $\downarrow$ & $\underline{F F 403901}$ \\
\hline No homologous region & 69 & 268 & - & $\downarrow$ & $\underline{\text { FF403902 }}$ \\
\hline No homologous region & 70 & 240 & - & $\downarrow$ & FF403904 \\
\hline No homologous region & 71 & 495 & - & $\downarrow$ & $\underline{\text { FF403905 }}$ \\
\hline No homologous region & 72 & 519 & - & $\downarrow$ & $\underline{F F 403906}$ \\
\hline No homologous region & 75 & 402 & - & $\downarrow$ & $\underline{\text { FF403909 }}$ \\
\hline No homologous region & 76 & 342 & - & $\downarrow$ & $\underline{F F 403910}$ \\
\hline No homologous region & 77 & 555 & - & $\downarrow$ & $\underline{\text { FF403911 }}$ \\
\hline No homologous region & 79 & 338 & - & $\downarrow$ & $\underline{\text { FF403913 }}$ \\
\hline
\end{tabular}


Table 2

253

Primers used for real time quantitative PCR

254

\begin{tabular}{|c|c|c|c|c|}
\hline $\begin{array}{c}\text { EST } \\
\#\end{array}$ & $\begin{array}{c}\text { GenBank Access } \\
\text { No. }\end{array}$ & Forward Primer $\left(5^{\prime} \rightarrow 3^{\prime}\right)$ & Reverse Primer $\left(5^{\prime} \rightarrow 3^{\prime}\right)$ & $\operatorname{Tm}\left({ }^{\circ} \mathbf{C}\right)$ \\
\hline 1 & $\underline{F F 403837}$ & ACTATAATCCTTGAAAGTCCAGT & AACTTCAGTCTGAGCAACATG & 53 \\
\hline 2 & $\underline{\text { FF403848 }}$ & ACCTGAGGGACAGAAACG & TCCCAGAGCCACAACAC & 53 \\
\hline 3 & $\underline{F F 403859}$ & GAAATATCACAAGCGTGGC & GCTCATCTGAATCCCTTTTC & 53 \\
\hline 6 & $\underline{\text { FF403892 }}$ & ATAATCACCTACATTCATTGCT & TACCATCGGTCAACATTCTC & 53 \\
\hline 7 & $\underline{\text { FF403903 }}$ & AGAAAGAATACCCGGACAG & GCGATGACGTGGTCACA & 53 \\
\hline 8 & $\underline{\text { FF403914 }}$ & ATACAAAAGCAAAAACCCTAC & GCGAAATGCCCACAGA & 53 \\
\hline 9 & $\underline{\text { FF403915 }}$ & GCAAAATGTCCACCACTTC & GCACACCAAATCGCCA & 53 \\
\hline 10 & $\underline{\text { FF403838 }}$ & GTGCTACTCAAACTGGACCT- & AATATTTGCGATGAATGGAC & 53 \\
\hline 11 & $\underline{\text { FF403839 }}$ & GAAACCCACGCAGAACAG & AGCTCATCACCGAGGATG & 53 \\
\hline 12 & $\underline{\text { FF403840 }}$ & ATCTTGAAGTTGGCAGGG & ACTGGAAGGACTTGAACCC & 53 \\
\hline 13 & $\underline{\text { FF403841 }}$ & ACGGGCTTCTTTGATTTC & GAATCTGTTCGGCTCACTC & 53 \\
\hline 14 & $\underline{\text { FF403842 }}$ & CACAGACAGCGAGGAGGA & CGCCGTCATCATTTGTAC & 53 \\
\hline 15 & $\underline{\text { FF403843 }}$ & AAGAAGTCCATCGCCTACA & GGTTCCTGGGCTGTCTC & 53 \\
\hline 16 & $\underline{\text { FF403844 }}$ & TTTTGGGGGATTTTATGC & CACAGAAGATACCTTGGACAG & 53 \\
\hline 17 & $\underline{\text { FF403845 }}$ & CCTCATCATTCGTAGTCAGC & CACTTGGATAGGGGTTGG & 53 \\
\hline 18 & $\underline{\text { FF403846 }}$ & GAGAAGAGGGCTTTTAGAGAG & TTGATAGCAGTTGTAATTGTCTG & 53 \\
\hline 19 & $\underline{F F 403847}$ & TTGAATCACTTCСТCСТCTG & GCCAAGGCTATACCTGCT & 53 \\
\hline
\end{tabular}

255 


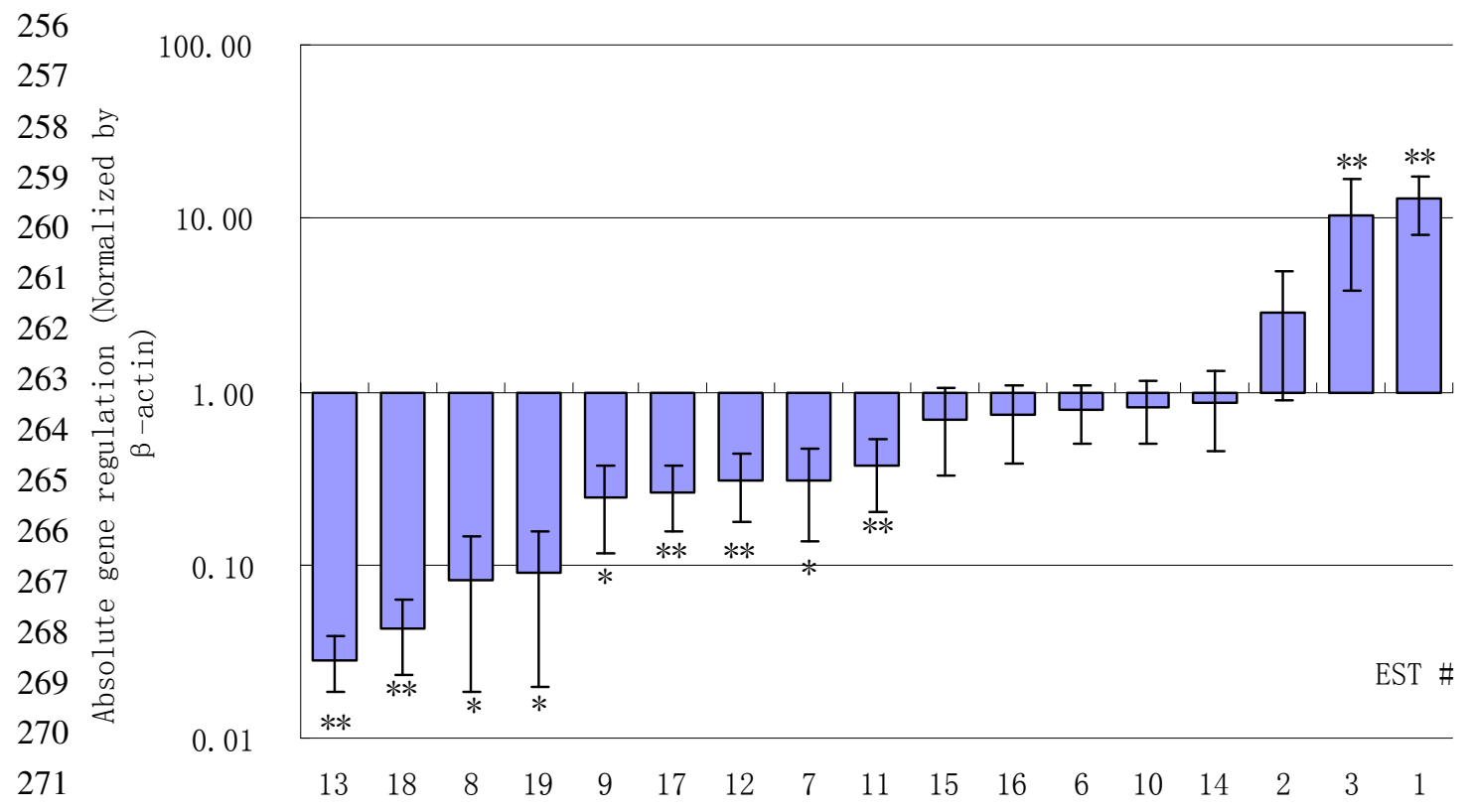

272

273 Figure 1. Gene expression profile of genes that were affected by PCBs.

274 The values were gene absolute regulation calculated by REST-MCS (C)- version 2 from

275 duplicate PCR determinations of three independent experiments for each set of conditions

276 tested (PCB-treated and the control). * \& ** indicate expression levels significantly

277 different from the control ( $p<0.05 \& p<0.01$ respectively) by Tukey's LSD.

278 